\title{
Meta-Analysis the Effect of Obesity on Polycystic Ovary Syndrome and Anemia in Women of Reproductive Age
}

\author{
Nabila Aulia Tsaqifah"), Rita Benya Adriani'), Bhisma Murti') \\ ${ }^{1)}$ Masters Program in Public Health, Universitas Sebelas Maret \\ ${ }^{2)}$ Health Polytechnics, Ministry of Health Surakarta
}

\section{ABSTRACT}

Background: Obesity in women of reproductive age is a nutritional problem that needs attention because obesity affects other health problems, especially problems of nutrient absorption and reproductive health. This needs special attention considering that the health of women of reproductive age has a major influence on the quality of future generations. The purpose of this study was to estimate the magnitude of the effect of obesity on the possibility of polycystic ovary syndrome (PCOS) and anemia in women of reproductive age.

Subjects and Method: Systematic review and meta-analysis. The data of this study used a research research design obtained from the databases of Google Scholar, PubMed, BMJ, ScienceDirect, SpingerLink, and Sage. The inclusion criteria used were full paper, crosssectional and cohort study designs with reported results adjusted odds ratio (aOR). Article searches were performed using the PICO model. Population $=$ women of reproductive age, Intervention $=$ Obesity, Comparison $=$ not obese , Outcome $=$ anemia and PCOS. Articles were collected using PRISMA diagrams and analyzed using the Review Manager application (RevMan5.3).

Results: A total of 10 articles on the relationship of obesity with anemia and 4 articles on the relationship of obesity with PCOS. Studies show that obesity reduced the risk of anemia compared to normal weight in women of reproductive age $(\mathrm{aOR}=0.73 ; 95 \% \mathrm{CI}=0.63$ to 0.84 ; $\mathrm{p}<0.001)$. Obesity increased the risk of PCOS 1.21 times compared to women with normal weight $(\mathrm{aOR}=1.21 ; 95 \% \mathrm{CI}=1.00$ to $1.48 ; \mathrm{p}=$ 0.050).

Conclusion: Obesity reduces the risk of anemia. Obesity increases the risk of PCOS in women of reproductive age.

Keywords: Obesity, anemia, PCOS, women of reproductive age.

\section{Correspondence:}

Nabila Aulia Tsaqifah. Masters Program in Public Health, Universitas Sebelas Maret. Jl. Ir. Sutami 36A, Surakarta 57126, Central Java. Email: auliatsaqifah@gmail.com. Mobile: 085607389109.

\section{Cite this as:}

Tsaqifah NA, Adriani RB, Murti B (2021). Meta-Analysis the Effect of Obesity on Polycystic Ovary Syndrome and Anemia in Women of Reproductive Age. J Matern Child Health. 06(04): 409-422. https://doi.org/10.26911/thejmch.2021.06.04.03.

c) (i) (2) Journal of Maternal and Child Health is licensed under a Creative Commons Attribution-NonCommercial-ShareAlike 4.o International License.

\section{BACKGROUND}

Obesity worldwide has almost tripled since 1975. In 2016, more than 1.9 billion adults were overweight. Of these, more than 650 million people are obese, of which $39 \%$ of adults are overweight and 13 percent are obese. In $201639 \%$ of the world's adult human population aged 18 years and over (39\% men and 40\% women) were over- weight, $13 \%$ of the world's adult human population (11\% men and $15 \%$ women) were obese (WHO, 2010). 2020).

Obesity and overweight in women of reproductive age affect reproductive health, including hormonal imbalances, irregular menstrual cycles and also absorption of nutrients that can cause anemia, these problems are things that need to be 
considered considering the health quality of women of reproductive age had important impact on the health of the next generation.

Anemia is defined as a low concentration of hemoglobin $(\mathrm{Hb})$ in the blood (WHO, 2020). One of the causes of obesityrelated anemia is adiposity which results in low-grade inflammation by activating interleukin-6 to induce hepcidin production. The increase in hepcidin inhibits the action of ferroportin so that iron persists in macrophages and hepatocytes thereby inhibiting the release of iron into plasma. In addition, the absorption of iron in entrocytes is also inhibited so that the decrease in the amount of iron in the plasma decreases (hypoferremia). This can reduce the potential for hemoglobin production so that it leads to the incidence of anemia due to inflammation (Cepeda-Lopez et al., 2011).

Research in Australia showed the prevalence of anemia and iron deficiency in obese women were $10 \%$ and $17 \%$, respectively, where the higher the body mass index, the lower serum iron, TIBC, and CReactive Protein (CRP) levels because obese subjects experienced an increase in iron deficiency. significant adiposity and inflammation (Cheng et al., 2013).

The impact of obesity independently and obesity-related anemia in women of reproductive age has an important effect on the quality of later life (intergeneration impact). The mechanism of the decrease in iron status in obese WUS is not only due to inflammation, there is monthly iron loss which can affect the increase in iron fulfillment (Nurramadhani., et al 2019).

Polycystic Ovary Syndrome (PCOS) is a collection of symptoms experienced by women of reproductive age in the form of amenorrhea, irregular menstruation, infertility, hirsutism, acne and androgenic alopecia. In PCOS the amount and distribution of body fat is often impaired by abdominal adiposity or obesity is often shown by women with PCO (Mareta et al., 2018) (Barber et al., 2019)

PCO patients with obesity were 2.7 times more likely to experience impaired ovarian follicle maturation process than PCO patients who were not obese $(\mathrm{OR}=2.7$; 95\% CI; 1.33-5.34; p=0.006) (Wahyuniet al., 2015). PCOS was also significantly associated with increased body mass index $(\mathrm{OR}=1.14)$, greater waist circumference $(\mathrm{OR}=1.06,95 \% \mathrm{CI}=1.01$ to 1.11$)$, hirsutism $(\mathrm{OR}=20.83,95 \% \mathrm{CI}=5.35$ to 81.13$)$, and amenorrhea $(\mathrm{OR}=0.18,95 \% \mathrm{CI}=0.04$ to o.69). A study conducted on 263 women found obese women with PCOS and $88 \%$ of menstrual cycle disorders, while $72 \%$ of women who were not obese (Handini and Marufat., 2018).

This study is expected to estimate the magnitude of the effect of obesity on the incidence of PCOS and anemia in women of reproductive age.

\section{SUBJECTS AND METHOD}

\section{Study Design}

This was a systematic review and meta-analysis with PRISMA flow diagram guidelines. The databases used include Google Scholar, PubMed, BMJ, ScienceDirect, Springer Link and Sage. The keywords used are "Polycystic ovary syndrome AND obesity AND women reproductive age", "Anemia AND obesity AND women reproductive age", "polycystic ovary syndrome AND anemia AND obesity AND women reproductive age AND adjusted odds ratio", " polycystic OR anemia OR obesity OR women reproductive age".

\section{Inclusion Criteria}

The author develops inclusion criteria, namely full text English articles with an observational study design, the analysis used is multivariate with adjusted odds 
ratio. The research subjects were women of reproductive age aged 15-49 years and the outcomes analyzed were PCOS and anemia.

\section{Exclusion Criteria}

The exclusion criteria in this study were RCT studies, case controls, quasi-experiments, study protocols and pilot studies, non-full text articles and not multivariate analysis studies.

\section{Operational Definition of Variables} The search for articles was carried out by considering the eligibility criteria defined using the PICO model. The population in the study were women of reproductive age with obesity intervention, comparison was not obese, outcomes experienced PCOS and/or anemia.

Obesity is an excessive accumulation of fat due to an imbalance between energy intake and energy expended for a long time with a BMI $30 \mathrm{~kg} / \mathrm{m} 2$. The instruments used are anthropometric calculations and categorical measurement scales.

PCOS is a heterogeneous endocrine disorder characterized by irregular menstruation, hyperandrogenism, and polycystic ovaries, with the diagnostic criteria for NIH, Rotterdam and Androgen Excess. The instruments used are medical records and categorical measurement scales.

Anemia is a condition where the concentration of hemoglobin $(\mathrm{Hb})$ is low in the blood with hemoglobin in the blood $<12$ $\mathrm{g} / \mathrm{dL}$. The research instrument used was medical records and categorical measurement scales.

\section{Instrument}

The study was conducted using the PRISMA flow chart guidelines and the assessment of the quality of research articles using the critical appraisal checklist for cross-sectional study, critical appraisal skills program (CASP) for cohort study (Checklist and How, 1994).

\section{Data Analysis}

The data in this study were analyzed using the RevMen 5.3 application, to calculate the effect size and heterogeneity of the study. The results of data processing are presented in the form of forest plots and funnel plots.

\section{RESULTS}

The article review process was carried out using the PRISMA flow chart, which can be seen in Figure 1.

The total articles obtained were 14 articles. The distribution of the article is on 5 continents with details of 8 from the Asian continent, 3 African continents, 1 America continent, 1 Australian continent, 1 European continent. Assessment of the quality of research articles with critical appraisal checklist for cross-sectional study, critical appraisal skills program (CASP) for cohort study can be seen in Tables 1, 2, and 3

\section{The effect of obesity on the risk of anemia in women of reproductive age}

Research related to the influence of obesity on the incidence of anemia in WUS comes from the continents of Asia, America and Africa, consisting of various countries including Indonesia, Japan, Nepal, Pakistan, India, Maldives, Rwanda, Ethiopia, North Ethiopia and Mexico. An overview of each study can be seen in Table 4 . 


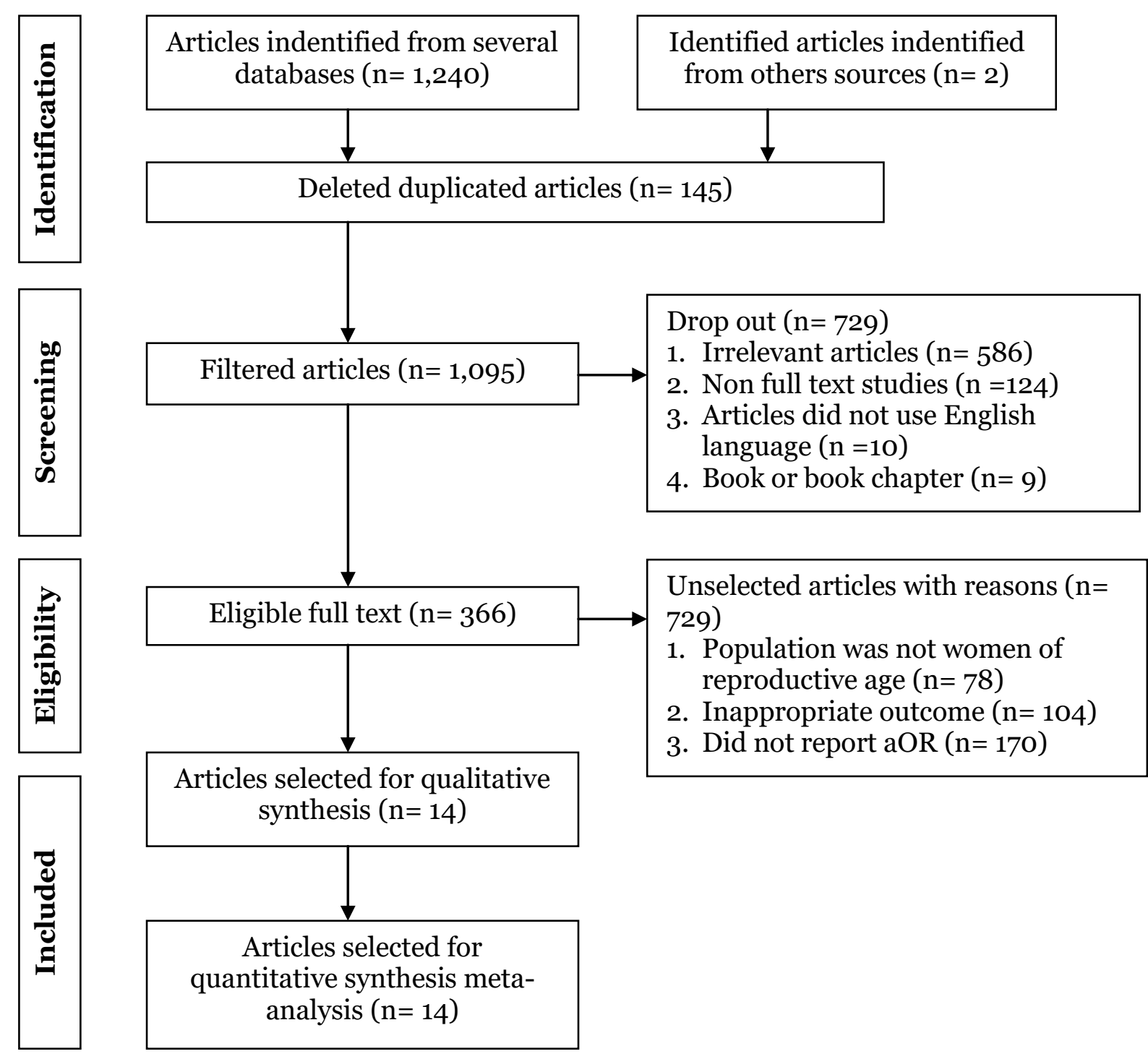

\section{Figure 1. Flow chart}

\section{a. Forest Plot}

The interpretation of the results of the meta-analysis of the relationship between obesity and the incidence of anemia in women of reproductive age can be seen through the forest plot. Figure 2 shows that there is an effect of reducing the risk of anemia. Women of reproductive age with obesity had $3 / 4$ times the risk of anemia compared to women of reproductive age with normal weight $(\mathrm{aOR}=0.73 ; 95 \% \mathrm{CI}=$ 0.63 to $0.84 ; \mathrm{p}<0.001)$. The heterogeneity of the research data shows $\mathrm{I}^{2}=68 \%$ so that the distribution of the data is said to be heterogeneous (random effect model). 
Tsaqifah et al./ Effect of Obesity on Polycystic Ovary Syndrome and Anemia

Odds Ratio Odds Ratio

Study or Subgroup log[Odds Ratio] SE Weight IV, Random, $95 \% \mathrm{Cl} \quad$ IV, Random, $95 \% \mathrm{Cl}$

\begin{tabular}{|c|c|c|c|c|c|c|c|c|}
\hline Gautam et al 2019 & .0 .4463 & 0.1158 & $13.8 \%$ & $0.64(0.51,0.80)$ & & $\mp$ & & \\
\hline Gebremedhi et al 2011 & -0.462 & 0.1495 & $11.4 \%$ & $0.63[0.47,0.84]$ & & $\leftarrow$ & & \\
\hline Habib et al 2018 & -0.5108 & 0.1943 & $8.7 \%$ & $0.60[0.41,0.88]$ & & $\rightarrow$ & & \\
\hline Hakizima et al 2019 & -0.5108 & 0.2069 & $8.1 \%$ & $0.60[0.40,0.90]$ & & $\longrightarrow$ & & \\
\hline Hisa K et al 2019 & .0 .9943 & 1.0212 & $0.5 \%$ & $0.37[0.05,2.74]$ & & & & \\
\hline Lopez et al 2011 & 0.6523 & 0.2272 & $7.2 \%$ & $1.92[1.23,3.00]$ & & & $\rightarrow$ & \\
\hline Sunuwar et al 2020 & -0.1985 & 0.1185 & $13.6 \%$ & $0.82[0.65,1.03]$ & & 7 & & \\
\hline Sunuwar 2 et al 2020 & .0 .2744 & 0.0205 & $20.1 \%$ & $0.76[0.73,0.79]$ & & - & & \\
\hline Utami et al 2020 & -0.3857 & 0.0991 & $15.1 \%$ & $0.68[0.56,0.83]$ & &  & & \\
\hline Woldu et al 2020 & -1.3093 & 0.6206 & $1.4 \%$ & $0.27[0.08,0.91]$ & & & & \\
\hline Total $(95 \% \mathrm{Cl})$ & & & $100.0 \%$ & $0.73[0.63,0.84]$ & & $\boldsymbol{\nabla}$ & & \\
\hline \multicolumn{5}{|c|}{ Heterogeneity: Tau $^{2}=0.03 ; \mathrm{Chi}^{2}=27.93, \mathrm{df}=9(\mathrm{P}=0.0010) ; \mathrm{P}^{2}=68 \%$} & 0.01 & 0.1 & 10 & 100 \\
\hline
\end{tabular}

Figure 2. Forest Plot Effect of Obesity on Anemia

\section{b. Funnel Plot}

Based on Figure 3, the funnel plots the relationship between obesity and the incidence of anemia in women of reproductive age, the plots on the right and left are not symmetrical to each other and do not form an inverted funnel, where 7 plots are located on the right and 3 plots are located on the left. The funnel plots are not symmetrical in the small-sample primary study, which indicates there is a slight publication bias that overestimates the true effect.

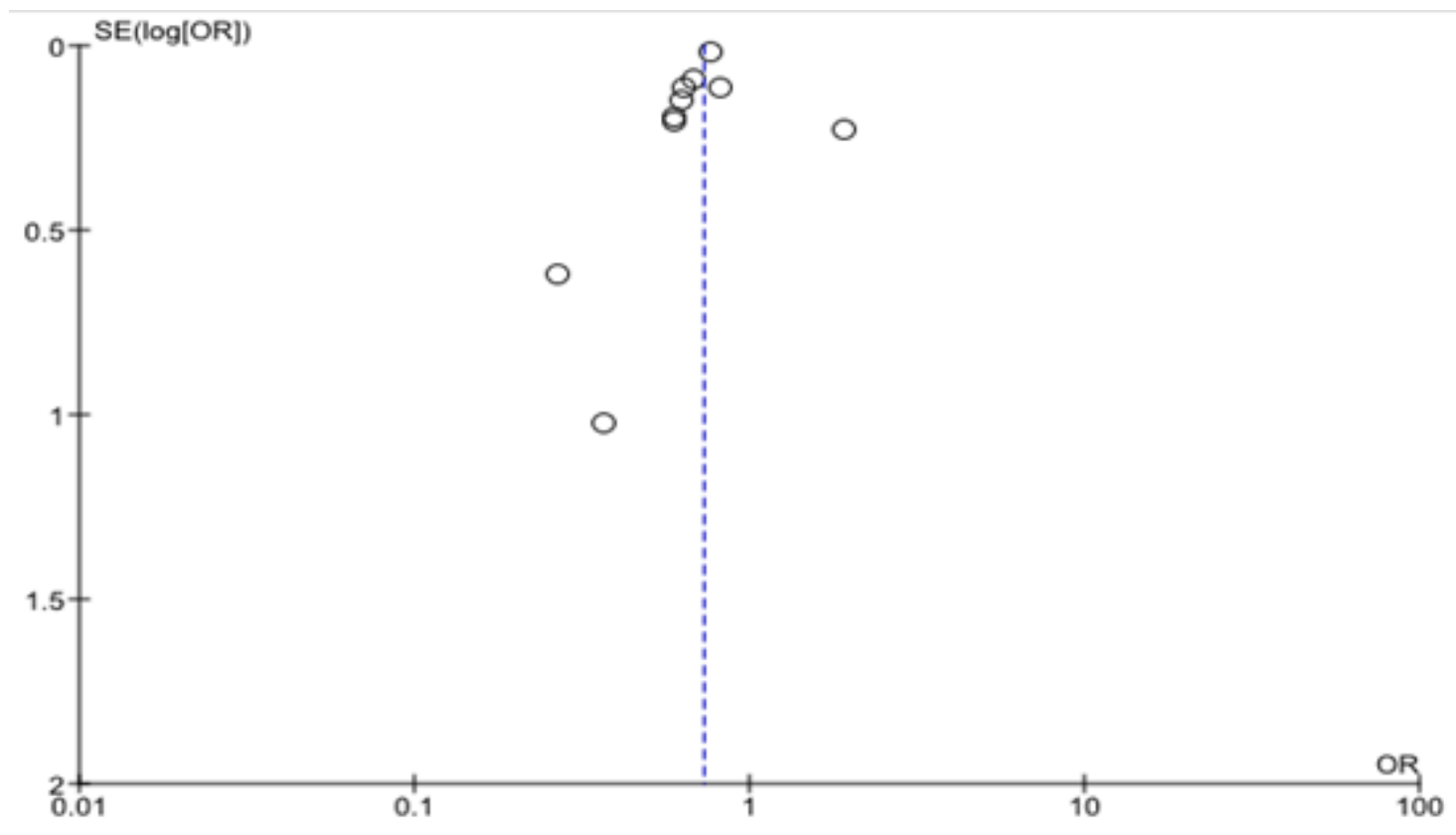

Figure 3. Funnel Plot Effect of Obesity on Anemia 
Table 1. Criteria for selecting articles

\begin{tabular}{|c|c|c|c|c|c|c|c|c|c|c|c|c|c|}
\hline \multirow[b]{2}{*}{$\begin{array}{c}\text { Primary } \\
\text { Study }\end{array}$} & \multicolumn{13}{|c|}{ Criteria } \\
\hline & $\begin{array}{c}\text { Research } \\
\text { focus/ } \\
\text { problem }\end{array}$ & $\begin{array}{c}\text { Study } \\
\text { Design }\end{array}$ & $\begin{array}{l}\text { Sample } \\
\text { selec- } \\
\text { tion }\end{array}$ & $\begin{array}{c}\text { Selection of } \\
\text { research } \\
\text { subjects \& } \\
\text { Minimizing } \\
\text { bias }\end{array}$ & $\begin{array}{c}\text { The } \\
\text { sample } \\
\text { represents } \\
\text { the popu- } \\
\text { lation }\end{array}$ & $\begin{array}{c}\text { Sample } \\
\text { size by } \\
\text { pre-study }\end{array}$ & $\begin{array}{c}\text { Satis- } \\
\text { factory } \\
\text { response }\end{array}$ & $\begin{array}{l}\text { Valid Rese- } \\
\text { arch Instru- } \\
\text { ments }\end{array}$ & $\begin{array}{c}\text { Statis- } \\
\text { tical } \\
\text { signi- } \\
\text { ficance }\end{array}$ & CI & $\begin{array}{l}\text { Con- } \\
\text { found- } \\
\text { ing } \\
\text { factors }\end{array}$ & $\begin{array}{l}\text { Applied } \\
\text { results }\end{array}$ & Total \\
\hline $\begin{array}{l}\text { Hazkimana } \\
\text { et al. } \\
(\mathbf{2 0 1 9})\end{array}$ & 1 & 1 & 1 & O & 1 & $\mathrm{O}$ & 1 & 1 & 1 & 1 & 1 & 1 & 9 \\
\hline $\begin{array}{l}\text { Utami et al. } \\
(2020)\end{array}$ & 1 & 1 & 1 & 1 & 1 & 1 & 1 & 1 & 1 & 1 & 1 & 1 & 12 \\
\hline $\begin{array}{l}\text { Lopez et al } \\
\text { (2011) }\end{array}$ & 1 & 1 & $\mathrm{O}$ & 1 & 1 & 0 & 1 & 1 & 1 & 1 & 1 & 1 & 12 \\
\hline $\begin{array}{l}\text { Gautam } \\
(2019)\end{array}$ & 1 & 1 & $\mathrm{O}$ & 1 & 1 & O & 1 & 1 & 1 & 1 & 1 & 1 & 10 \\
\hline $\begin{array}{l}\text { Sunuwar } \\
(2020)\end{array}$ & 1 & 1 & 1 & 1 & 1 & O & 1 & 1 & 1 & 1 & 1 & 1 & 11 \\
\hline $\begin{array}{l}\text { Gebremed } \\
\text { hin (2011) }\end{array}$ & 1 & 1 & 1 & 1 & 1 & 0 & 1 & 1 & 1 & 1 & 1 & 1 & 11 \\
\hline $\begin{array}{l}\text { HabibAtif } \\
\text { et al. } \\
\text { (2018) }\end{array}$ & 1 & 1 & 1 & o & 1 & 1 & 1 & 1 & 1 & 1 & 1 & 1 & 11 \\
\hline $\begin{array}{l}\text { Woldu et } \\
\text { al. (2020) }\end{array}$ & 1 & 1 & 1 & O & 1 & 1 & 1 & 1 & 1 & 1 & 1 & 1 & 11 \\
\hline $\begin{array}{l}\text { Hisa et al. } \\
\text { (2019) }\end{array}$ & 1 & 1 & 1 & 1 & 1 & 0 & 1 & 1 & 1 & 1 & 1 & 1 & 11 \\
\hline
\end{tabular}


Table 1. Assessment of the Quality of Research Cross-sectional design Article Relationship between Obesity and Anemia

\begin{tabular}{|c|c|c|c|c|c|c|c|c|c|c|c|c|c|}
\hline \multirow[b]{2}{*}{$\begin{array}{l}\text { Primary } \\
\text { Study }\end{array}$} & \multicolumn{12}{|c|}{ Criteria } & \multirow[b]{2}{*}{ Total } \\
\hline & $\begin{array}{c}\text { Research } \\
\text { focus/ } \\
\text { problem }\end{array}$ & $\begin{array}{c}\text { Research } \\
\text { design }\end{array}$ & $\begin{array}{c}\text { Sample } \\
\text { selection }\end{array}$ & $\begin{array}{c}\text { Selection of } \\
\text { research subjects } \\
\text { \& minimizing } \\
\text { bias }\end{array}$ & $\begin{array}{c}\text { The sample } \\
\text { represents } \\
\text { the } \\
\text { population }\end{array}$ & $\begin{array}{c}\text { Sample } \\
\text { size }\end{array}$ & $\begin{array}{c}\text { Satis- } \\
\text { factory } \\
\text { response }\end{array}$ & $\begin{array}{c}\text { Valid } \\
\text { Research } \\
\text { Instru- } \\
\text { ments } \\
\end{array}$ & $\begin{array}{l}\text { Statis- } \\
\text { tical } \\
\text { signi- } \\
\text { ficance }\end{array}$ & CI & $\begin{array}{l}\text { Confound- A } \\
\text { ing factors }\end{array}$ & $\begin{array}{l}\text { Applied } \\
\text { results }\end{array}$ & \\
\hline $\begin{array}{l}\text { Esmailzad } \\
\text { ehet al } \\
\text { (2014) }\end{array}$ & 1 & 1 & 1 & 1 & 1 & o & 1 & 1 & 1 & 1 & 1 & 1 & 11 \\
\hline $\begin{array}{l}\text { Mu et al } \\
\text { (2018) }\end{array}$ & 1 & 1 & 1 & 1 & 1 & 1 & 1 & 1 & 1 & 1 & 1 & 1 & 12 \\
\hline $\begin{array}{l}\text { Usta et al. } \\
\text { (2018) }\end{array}$ & 1 & 1 & $\mathrm{o}$ & 1 & 1 & $\mathrm{o}$ & 1 & 1 & 1 & 1 & 1 & 1 & 10 \\
\hline
\end{tabular}

$$
\text { Note: }
$$

Answer $1=$ yes

Answer $0=$ no

Table 2. Assessment of the Quality of research cross-sectional design articles relationship between obesity and PCOS

\begin{tabular}{|c|c|c|c|c|c|c|c|c|c|c|c|c|c|}
\hline \multirow[b]{2}{*}{ Primer study } & \multicolumn{12}{|c|}{ Criteria } & \multirow[b]{2}{*}{ Total } \\
\hline & $\begin{array}{c}\text { Focus } \\
\text { study } \\
\text { /problem }\end{array}$ & $\begin{array}{l}\text { Study } \\
\text { design }\end{array}$ & $\begin{array}{l}\text { Sample } \\
\text { selec- } \\
\text { tion }\end{array}$ & $\begin{array}{c}\text { Study subjects } \\
\text { selection and } \\
\text { bias minimize }\end{array}$ & $\begin{array}{c}\text { Sample } \\
\text { represent } \\
\text { population }\end{array}$ & $\begin{array}{l}\text { Appro- } \\
\text { priate } \\
\text { sample } \\
\text { size } \\
\end{array}$ & $\begin{array}{l}\text { Satisfied } \\
\text { response }\end{array}$ & $\begin{array}{c}\text { Validity } \\
\text { of the } \\
\text { instru- } \\
\text { ment } \\
\end{array}$ & $\begin{array}{l}\text { Statistic } \\
\text { signi- } \\
\text { fication }\end{array}$ & CI & $\begin{array}{l}\text { Uncoun } \\
\text { ted } \\
\text { confoun } \\
\text { ding } \\
\end{array}$ & $\begin{array}{l}\text { Imple- } \\
\text { mented } \\
\text { result }\end{array}$ & \\
\hline $\begin{array}{l}\text { Esmailzadeh et } \\
\text { al. (2014) }\end{array}$ & 1 & 1 & 1 & 1 & 1 & 0 & 1 & 1 & 1 & 1 & 1 & 1 & 11 \\
\hline Mu et al. (2018) & 1 & 1 & 1 & 1 & 1 & 1 & 1 & 1 & 1 & 1 & 1 & 1 & 12 \\
\hline Usta et al. (2018) & 1 & 1 & o & 1 & 1 & o & 1 & 1 & 1 & 1 & 1 & 1 & 10 \\
\hline
\end{tabular}

Note:

Answer $1=$ yes

Answer $\mathrm{O}=$ no 
Table 3. Assessment of Research Quality in Article Cohort Design The Relationship between Obesity and PCOS

\begin{tabular}{|c|c|c|c|c|c|c|c|c|c|c|c|c|c|}
\hline \multirow[b]{2}{*}{$\begin{array}{l}\text { Primer } \\
\text { study }\end{array}$} & \multicolumn{12}{|c|}{ Criteria } & \multirow[b]{2}{*}{ Total } \\
\hline & $\begin{array}{c}\text { Study } \\
\text { focus/ } \\
\text { proble } \\
\text { m }\end{array}$ & $\begin{array}{c}\text { Cohort } \\
\text { selected } \\
\text { properly }\end{array}$ & $\begin{array}{l}\text { Exposure } \\
\text { measured } \\
\text { accurately }\end{array}$ & $\begin{array}{c}\text { Results } \\
\text { measured } \\
\text { accurately }\end{array}$ & $\begin{array}{l}\text { Identify and } \\
\text { control } \\
\text { confound- } \\
\text { ing factors }\end{array}$ & $\begin{array}{l}\text { Complete } \\
\text { follow up }\end{array}$ & $\begin{array}{l}\text { Results } \\
\text { study }\end{array}$ & $\begin{array}{c}\text { Results } \\
\text { precision }\end{array}$ & $\begin{array}{c}\text { Eligible } \\
\text { study }\end{array}$ & $\begin{array}{c}\text { Results can } \\
\text { be } \\
\text { implemente } \\
\text { d in local } \\
\text { population }\end{array}$ & $\begin{array}{c}\text { Results are } \\
\text { appropriate } \\
\text { with } \\
\text { evidence }\end{array}$ & $\begin{array}{c}\text { Study } \\
\text { imply- } \\
\text { cation }\end{array}$ & \\
\hline $\begin{array}{l}\text { Teede } \\
\text { et al. } \\
(2013)\end{array}$ & 1 & 1 & 1 & 1 & 1 & o & 1 & 1 & 1 & 1 & 1 & 1 & 11 \\
\hline
\end{tabular}

Note:

Answer 1 = yes

Answer $0=$ no

Table 4. Description of the primary study of the effect of obesity on the incidence of anemia in women of reproductve age

\begin{tabular}{|c|c|c|c|c|c|c|c|}
\hline $\begin{array}{l}\text { Author } \\
\text { (Year) }\end{array}$ & Country & Study Design & Sample & $\begin{array}{c}\mathbf{P} \\
\text { (Population) }\end{array}$ & $\begin{array}{c}\text { I } \\
\text { (Intervention) }\end{array}$ & $\begin{array}{c}\mathrm{C} \\
\text { (Comparison) }\end{array}$ & $\begin{array}{c}\text { O } \\
\text { (Outcome) }\end{array}$ \\
\hline Hakizima et al (2019) & $\begin{array}{l}\text { Rwada, East } \\
\text { Africa }\end{array}$ & Cross-sectional & 6680 & Women aged $15-49$ years & Obesity & No Obesity & Anemia \\
\hline Utami et al. (2020) & Indonesia & Cross-sectional & 3667 & Women of reproductive age & Obesity & No Obesity & Anemia \\
\hline Lopez et al (2011) & Mexico & Cross-sectional & 621 & Women aged $18-50$ years & Obesity & No Obesity & $\begin{array}{l}\text { Zinc } \\
\text { deficiency } \\
\text { anemia }\end{array}$ \\
\hline Gautam et al (2019) & Nepal & Cross-sectional & 6414 & Women aged $15-49$ years & Obesity & No Obesity & Anemia \\
\hline Sunuwar et al (2020) & India & Cross-sectional & 679,445 & Women aged 15-35 & Obesity & No Obesity & Anemia \\
\hline Sunuwar et al (2020) & Maldives & Cross-sectional & 6,653 & Women aged $15-35$ & Obesity & No Obesity & Anemia \\
\hline $\begin{array}{l}\text { Gebremedhi et al } \\
\text { (2011) }\end{array}$ & Ethiopia & Cross-sectional & 5,963 & Women aged $15-49$ years & Obesity & No Obesity & Anemia \\
\hline Habib et al (2018) & Pakistan & Cross-sectional & 27,963 & Women aged $15-49$ years & Obesity & No Obesity & Anemia \\
\hline Hisa et al (2019) & Japan & Cross-sectional & 10,598 & Women aged 20-49 years old & Obesity & No Obesity & Anemia \\
\hline Woldu et al (2020) & $\begin{array}{l}\text { Northeast } \\
\text { Ethiopia }\end{array}$ & Cross-sectional & 359 & Women aged $15-49$ years & Obesity & No Obesity & Anemia \\
\hline
\end{tabular}


Tsaqifah et al./ Effect of Obesity on Polycystic Ovary Syndrome and Anemia

Table 5. Description of the primary study article relationship between obesity and PCOS

\begin{tabular}{|c|c|c|c|c|c|c|c|}
\hline Author (Year) & Country & Study Design & Sample & $\begin{array}{c}\mathbf{P} \\
\text { (Population) }\end{array}$ & $\begin{array}{c}\text { I } \\
\text { (Intervention) }\end{array}$ & $\begin{array}{c}\mathrm{C} \\
\text { (Comparison) }\end{array}$ & $\begin{array}{c}\text { O } \\
\text { (Outcome) }\end{array}$ \\
\hline $\begin{array}{l}\text { Esmaeilzadeh et al. } \\
\text { (2014) }\end{array}$ & $\begin{array}{l}\text { Iranian } \\
\text { Babol }\end{array}$ & Cross-sectional & 175 & Female $18-38$ years old & Obesity & No Obesity & PCOS \\
\hline Mu et al. (2018) & China & Cross-sectional & 3,565 & Women aged $19-45$ years & Obesity & No Obesity & PCOS \\
\hline Teede et al. (2013) & Australia & Cohort & 9,145 & Women of reproductive age & Obesity & No Obesity & PCOS \\
\hline Usta et al. (2018) & Turkey & Cross-sectional & 124 & Women aged 28-33 years & Obesity & No Obesity & PCOS \\
\hline
\end{tabular}


Tsaqifah et al./ Effect of Obesity on Polycystic Ovary Syndrome and Anemia

\section{The relationship between obesity and PCOS in women of reproductive age.}

Research on the relationship between obesity and PCOS in women of reproductive age. The article comes from the continents of Asia, Australia and Europe, consisting of China, Iran, Turkey, and Australia. An overview of each study can be seen in Table 5 .

\section{a. Forest Plot}

The interpretation of the results of the metaanalysis of the relationship between obesity and the incidence of PCOS in women of reproductive age can be seen through the forest plot. Figure 4 shows that there is an effect of obesity on the increase in the incidence of PCOS in women of reproductive age. Women of reproductive age with obesity had 1.21 times the risk of PCOS compared to women of reproductive age with normal weight $(\mathrm{aOR}=1.21 ; 95 \% \mathrm{CI}=1.00$ to $1.48 ; \mathrm{p}=$ 0.050). The heterogeneity of the research data shows $\mathrm{I}^{2}=90 \%$ so that the distribution of the data is declared heterogeneous (random effect model).



\section{Figure 4. Forest Plot Relationship of Obesity with PCOS Incidence}

\section{b. Funnel Plot}

Based on Figure 5, the funnel plot of the relationship between obesity and the incidence of PCOS in women of repro- ductive age shows that the funnel plot is quite symmetrical in the small sample primary study, which indicates that there is no publication bias. 


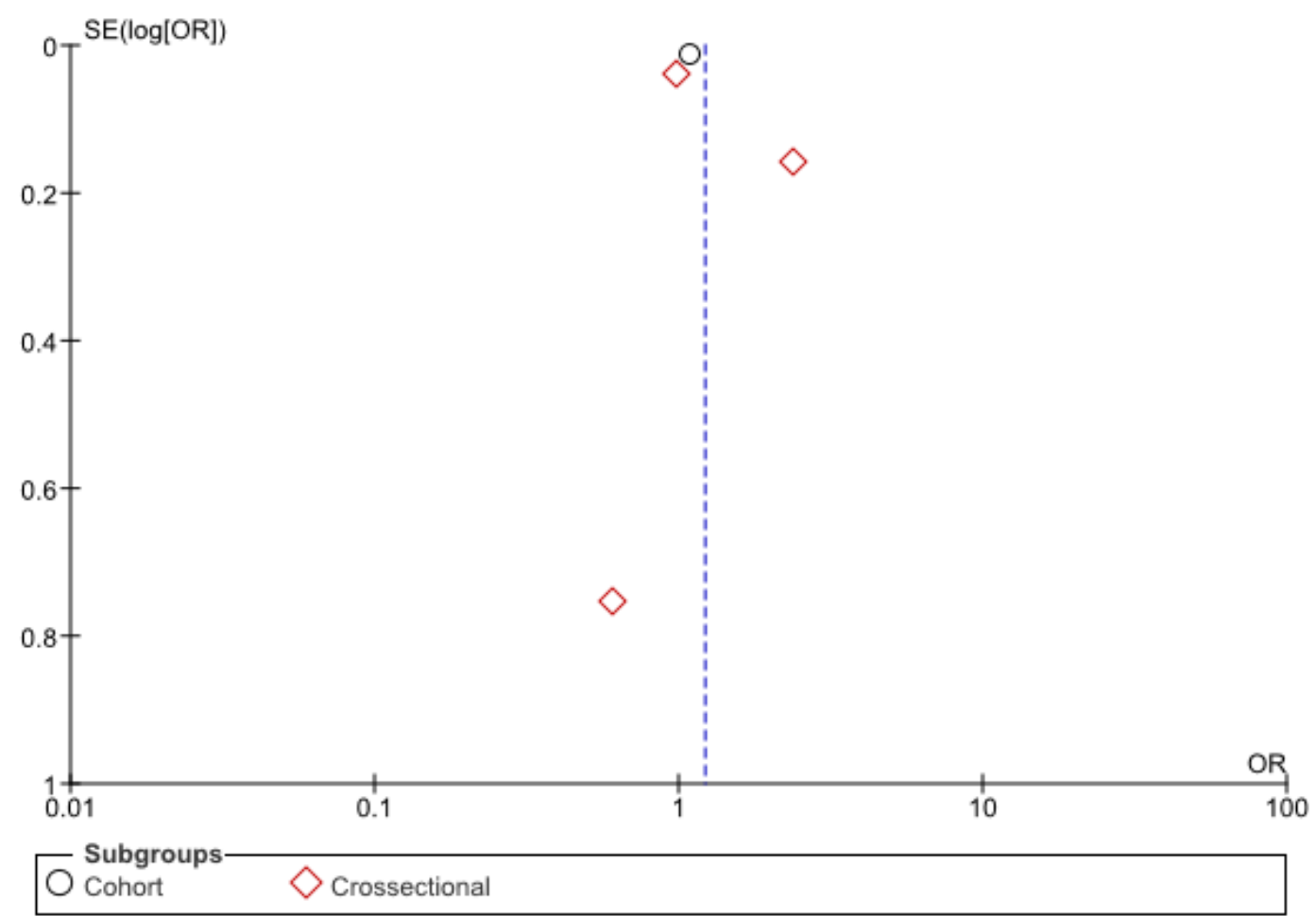

\section{Figure 5. Funnel plot relationship of obesity with PCOS incidence}

\section{DISCUSSION}

This systematic review and meta-analysis studies the effect of obesity on the incidence of PCOS and anemia in women of reproductive age. The independent variable in this study was obesity in women of reproductive age and the dependent variables analyzed were PCOS and anemia in women of reproductive age. This metaanalysis study was conducted using a study that controlled for confounding factors because the research involved was a study that used multivariate analysis and the statistical results reported were adjusted odds ratio (aOR). The combined estimates of the association of obesity with the incidence of anemia and PCOS in women of reproductive age were processed using the RevMan 5.3 application. The results of the systematic study and meta-analysis are presented in the form of forest plots and funnel plots.

\section{The effect of obesity on anemia in women of reproductive age.}

There are 10 research articles from various countries using observational methods that can be used as sources for this metaanalysis research. The results of the forest plot show that there is an effect of reducing the risk of anemia in women of reproductive age with obesity. Women of reproductive age with obesity had 3/4 times the risk of anemia compared to women of reproductive age with normal weight $(\mathrm{aOR}=0.73$; $95 \% \mathrm{CI}=0.63$ to $0.84 ; \mathrm{p}<0.001)$.

This is in line with Utami et al. (2020) which aims to determine the determinants of factors that influence the occurrence of anemia in Indonesia which shows that underweight nutritional status increases the risk of anemia 1.5 times compared to women of reproductive age with normal $\mathrm{BMI}(\mathrm{aOR}=1.48 ; 95 \% \mathrm{CI}=1.07$ to $2.05 ; \mathrm{p}=$ o.017), while obesity reduced the likelihood of anemia by $33 \%(\mathrm{aOR}=0.67 ; 95 \% \mathrm{CI}=0.56-$ 
o.80) compared to other nutritional statuses.

Nutritional status of obesity in research conducted in China and Taiwan found that women of reproductive age with obesity consume high levels of vitamin $\mathrm{C}$ and iron compared to underweight nutritional status which has an essential micronutrient deficit associated with anemia. In a study in Taiwan, there was a positive relationship between body mass index (BMI) and serum ferritrin and hemoglobin levels, where the higher the BMI, the higher the serum ferritrin and hemoglobin levels in women aged 19 years and over. Overweight $(\mathrm{OR}=0.36 ; 95 \% \mathrm{CI}=0.18-0.73)$ and Obese $(\mathrm{OR}=0.48 ; 95 \% \mathrm{CI}=0.26-0.89)$ showed $\mathrm{a}$ positive effect on iron deficiency anemia (IDA) compared to normal weight (Chang et al., 2014) .

The results of the bivariate analysis conducted by (Utami et al., 2020) showed that most of the obese women in the study subjects used hormonal contraception, where hormonal contraception had an effect on body weight, with an average increase of 0-1 $\mathrm{kg}$ per year. Women who use hormonal contraception also usually experience amenorrhea, which may cause obesity to be one of the low risk factors for anemia, due to a reduction in menstrual blood loss compared to women who experience normal menstrual cycles.

\section{Effect of obesity on PCOS in women of reproductive age}

There are 4 research articles from various countries using observational methods that can be used as sources for meta-analysis research. The results of the forest plot show that there is an effect of obesity on the increase in the incidence of PCOS in women of reproductive age. Women of reproductive age with obesity had 1.21 times the risk of PCOS compared to women of repro- ductive age with normal weight $(\mathrm{aOR}=1.21$; 95\% $\mathrm{CI}=1.00$ to $1.48 ; \mathrm{p}=0.050$ ).

These results are in accordance with the results of a meta-analysis conducted by (Lim et al., 2013) which aims to assess the prevalence of overweight, obesity and central obesity in women with PCOS, where women of reproductive age with PCOS increase the prevalence of overweight $(\mathrm{RR}=$ 1.95; $95 \% \mathrm{CI}=1.52$ to 2.50$)$, obesity $(\mathrm{RR}=$ 2.77; 95\% $\mathrm{CI}=1.88-4.10)$ and central obesity $(\mathrm{RR}=1.73 ; 95 \% \mathrm{CI}=1.31$ to 2.30$)$.

Zhang et al. (2014) showed that there was a significant relationship between body mass index $(\mathrm{OR}=1.94 ; \mathrm{p}=0.047)$, hirsutism $(\mathrm{OR}=8.36 ; \mathrm{p}=0.003)$ and polycystic ovary syndrome. Women with PCOS have a higher body mass index than women who are not diagnosed with PCOS.

According to Rojas (2014) in obesity there is a disturbance in hunger control, resulting in an increase in glucose intake, an increase in glucose intake will cause hyperinsulin which will secrete adrenal steroids resulting in hyperandrogens (Rojas et al., 2014).

Women of reproductive age with obesity tend to be more at risk of increasing insulin resistance which causes theca cells to produce androgens and inhibit sex hormone blinding globuline (SHBG) so that free androgens increase. This situation causes many androgens to be aromatized into estrogen which produces $\mathrm{LH}$ and triggers incomplete follicle maturation (Kasim-Karakas et al., 2007).

Seeing the magnitude of the risk factors for PCOS in women of reproductive age with obesity reported in several previous studies, good health management and promotion is needed to prevent obesity in women of reproductive age which can cause various other health problems, one of which is of concern is the reproductive health that can increase the incidence of PCOS. 
Lifestyle modification is one of the things that is needed to prevent obesity in women of reproductive age, health promotion about the importance of balanced nutritional intake and maintaining body mass index within normal limits needs to be socialized as early as possible, especially in adolescence, so that when women have entered the age of have a good nutritional status and a healthy reproductive health condition. This is expected to improve the health quality of the next generation.

\section{AUTHOR CONTRIBUTION}

Nabila Aulia Tsaqifah is the main researcher who selects the topic, searches and collects research data. Rita Benya Andriani and Bhisma Murti played a role in analyzing data and reviewing research documents. analyze data and review research documents.

\section{FUNDING AND SPONSORSHIP}

This study is self-funded.

\section{CONFLICT OF INTEREST}

There is no conflict of interest in this study.

\section{ACKNOWLEDGEMENT}

We are very grateful to the database providers Google Scholar, PubMed, Sage, BMJ, Clinical Key, and Springer Link.

\section{REFERENCE}

Barber TM, Hanson P, Weickert OM, Frank $S$ (2019). Obesity and polycystic ovary syndrome: implications for pathogenesis and novel management strategies. Clin Med Insights Reprod Health. 13: 117955811987404. https://doi.org/10.1177/1179558119874042.

Cepeda-Lopez AC, Osendrap S, MelseBostra A (2011). Sharply higher rates of iron deficiency in obese Mexican women and children are predicted by obesity-related inflammation rather than by differences in dietary iron intake. Am J Clin Nutr. 93(5): 975983. doi: 10.3945/ajen.110.005439.

Checklist C, How CS (1994). Critical appraisal skills programme (2018). CASP (insert name of checklist i.e. Cohort Study) Checklist.

Chang JS, Chen YC, Owaga E, Palupi KC, Pan WH, Bai $\mathrm{CH}$ (2014). Interactive effects of dietary fat/carbohydrate ratio and body mass index on iron deficiency anemia among Taiwanese women. Nutrients, 6(9): 3929-3941. https://doi.org/10.3390/nu6093929.

Cheng HL, Bryant C, Rooney K, Steinbeck SK, Groffin HJ, Petocz P, Connor H (2013). Iron, hepcidin and inflammatory status of young healthy overweight and obese women in Australia. PLoS ONE, 8(7): 1-6. doi: 10.1371/journal.pone.0068675.

Kasim-Karakas SE, Cunningham WM, Tsodikov A (2007). Relation of nutrients and hormones in polycystic ovary syndrome. Am J Clin Nutr. 85(3): 688-694. doi: 10.1093/ajcn/85.3.688.

Mareta R, Amran R, Larasati V (2018). Hubungan polycystic ovary syndrome (PCOS) dengan infertilitas di praktik swasta dokter obstetri ginekologi Palembang. Majalah Kedokteran Sriwijaya. 50(2): 85-91. Available at: https://ejournal.unsri.ac.id/index.ph $\mathrm{p} / \mathrm{mks} /$ article/view/8552.

Mayulu N, Novutasary DM, Kawengian S (2013). Hubungan antara aktivitas fisik dengan obesitas pada wanita usia subur peserta Jamkesmas di puskesmas Wawonasa Kecamatan Singkil Manado (The relationship between physical activity with obesity in women of reproductive age participated in national health insurance in 
Wawonasa, Singkil sub-district, Manado). E-BIOMEDIK. 1(2): 10401046. https://doi.org/10.35790/ebm.v1i2.3255.

Murti B (2018). Prinsip dan metode riset metodologi (Principles and methods of research methodology). Surakarta: UNS.

Rojas J, Chavez M, Olivar L, Rojas M, Morillio J, Calvo M, Bermudez V (2014). Polycystic ovary syndrome, insulin resistance, and obesity: Navigating the pathophysiologic labyrinth. Int J Reprod Med. 2014: 719050. https://doi.org/10.1155/2014/719050

Handini AT, Mirfat M (2018). Hubungan usia dan obesitas dengan infertilitas pada pasien di rumah sakit kepresidenan RSPAD Gatot Soebroto. (The relationship between age and obesity with infertility in patients at the presidential hospital of the Gatot Soebroto Hospital). Majalah Kesehatan Pharmamedika. 9(1): 33-39. doi: https://doi.org/10.33476/mkp.v9i1.6 73.

Utami PS, Ani LS, Lubis DS, Wirawan DN (2020). Determinants of anemia in women of reproductive age in Indonesia: Secondary data analysis of the 2018 Indonesia Basic Health Research. Public Health Prev Med Arch. 8(2): 86-91. https://doi.org/10.15562/phpma.v8i2.301.

WHO (2020) Obesity, WHO. Available at: https://www.who.int/news-room/fact-sheets/detail/obesity-and-overweight. 